\title{
TINJAUAN HUKUM EKONOMI ISLAM TERHADAP PRAKTIK JUAL BELI MOKE
}

\author{
Siti Amina Hardianti, Hamsir \\ Universitas Islam Negeri Alauddin Makassar \\ Email: sitiaminahardianti28@gmail.com
}

\begin{abstract}
Abstrak
Penelitian ini bertujuan ini mengangkat permasalahan tentang bagaimanakah tinjauan hukum ekonomi Islam terhadap praktik jual beli moke di kelurahan Nangamese, Kecamatan Riung, Kabupaten Ngada. Metode penelitian yang digunakan adalah kualitatif. Penelitian ini dilakukan di Kelurahan Nangamese dengan cara melakukan wawancara kepada penjual moke dan beberapa masyarakat yang berada di kelurahan tersebut. Hasil penelitian menunjukan bahwa, penjualan moke di kelurahan Nangamese dilakukan dengan tiga cara yakni: (1) dilakukan dengan cara terbuka karena tidak ada larangan dari pihak yang berwajib, (2) pembeli atau yang ingin mengkonsumsi moke tersebut mereka yang mendatangi penjual untuk bertransaksi langsung, (3) setiap penjual sudah mempunyai pelanggan tetap.
\end{abstract}

Kata Kunci: Ekonomi Islam, Jual Beli, Moke

\section{Abstract}

This study aims to raise the issue of how to review Islamic economic law on the practice of buying and selling moke in Nangamese village, Riung district, Ngada district. The research method used is qualitative. This research was conducted in Nangamese Village by conducting interviews with moke sellers and several people in the village. The results showed that the sale of moke in Nangamese village was carried out in three ways, namely: (1) carried out in an open way because there was no prohibition from the authorities, (2) buyers or those who wanted to consume the moke were those who came to the seller for direct transactions, (3) each seller already has a regular customer.

Keywords: Buy and Sell, Islamic Economics, Moke

\section{A. PENDAHULUAN}

Manusia sebagai makhluk hidup yang memiliki sifat konsumtif pasti membutuhkan makanan dan minuman. Sehingga dengan makanan dan minuman manusia dapat menjalankan aktivitas sehari-hari. Sebaliknya, jika tidak makan atau minum dalam waktu yang cukup lama maka akan berakibat fatal bagi kesehatan sehingga untuk beberapa kegiatan hidup dan kehidupan akan tertunda. Akan tetapi, tidak semua makanan dan minuman yang tersedia itu baik untuk dikonsumsi oleh manusia. Karena terdapat pula berbagai jenis makanan dan minuman yang tidak dianjurkan atau dilarang untuk kesehatan tubuh. Oleh karena itu, manusia sebagai makhluk yang diberikan akal oleh 
Allah swt. harus dapat membedakan mana yang boleh dikonsumsi mana yang tidak diperbolehkan.

Sebagai agama rahmatan lil-alamin Islam mengatur berbagai perilaku manusia dalam memenuhi kebutuhan hidupnya sehari-hari. Begitu pula dengan masalah konsumsi. Manusia diatur bagaimana melakukan kegiatan konsumsi yang berguna bagi kemaslahatan hidupnya. Islam telah mengatur jalan hidup manusia melalui al-Qur'an dan hadist agar manusia dijauhkan dari sifat yang hina karena perilaku konsumtifnya. Manusia hidup hanya untuk memperoleh kebahagian, manusia akan merasa bahagia ketika semua kebutuhan dan keinginannya terpenuhi, baik dalam aspek material maupun aspek spiritual. Belakangan ini, yang lebih banyak mendapatkan perhatian dalam ilmu ekonomi yaitu terpenuhinya kebutuhan material, inilah yang disebut dengan sejahtera. Perilaku konsumsi yang sesuai dengan ketentuan Allah dan Rasulullah saw. akan menjamin kehidupan yang lebih sejahtera. ${ }^{1}$

Tidak hanya mengatur tentang konsumsi, Islam juga mengatur segala hal tentang kegiatan manusia seperti kegiatan ekonomi, ibadah, perkawinan dan perceraian dan masih banyak kegiatan-kegiatan lainnya. Akan tetapi, lebih relevan dengan penulisan ini adalah masalah ekonomi khususnya jual beli. Perbincangan seputar ekonomi merupakan hal yang aktual dan menarik dikaji setiap saat. Masalah ini aktual dan menarik karena sejalan dengan perkembangan zaman, manusia tidak pernah luput dengan persoalan ekonomi dengan berbagai problematikanya. Saat ini, perkembangan ekonomi global yang semakin pesat memerlukan landasan kuat agar tidak mengalami benturan-benturan kepentingan. Ekonomi Islam hadir pada hakikatnya adalah metamorfosa nilai-nilai Islam dalam ekonomi dan dimaksudkan untuk menepis anggapan bahwa Islam adalah agama yang hanya mengatur persoalan ubudiyah atau komunikasi vertikal antara manusia (makhluk) dengan Allah. Ilmu ekonomi Islam dapat didefinisikan sebagai suatu cabang pengetahuan yang membantu merealisasikan kesejahteraan manusia melalui alokasi dan distribusi sumber-sumber daya alam dan manusia yang berlandaskan keadilan yang mesti diaktualisasikan. $^{2}$

Di era sekarang ini, terdapat berbagai problem yang secara kontekstual tidak terdapat didalam al-Qur'an ataupun hadits. Maka terhadap masalah-masalah yang tidak disebutkan didalam al-Qur'an atau tidak terdapat pada masa nabi, orang-orang selalu berusaha menafsirkan, mengqiyaskan, mengandaikan masalah-masalah tersebut dengan ketentuan-ketentuan al-Qur'an dan hadis yang bersifat global dan secara universal. ${ }^{3}$ Sehingga tidak sedikit perbedaan yang muncul, hal ini dikarenakan setiap orang, kelompok ataupun golongan tertentu memiliki penafsiran atau pola pikir yang berbeda pula, jadi tidak heran jika akan muncul berbagai perdebatan pendapat terhadap suatu permasalahan. Oleh karena penulisan ini lebih mengarah ke perilaku jual beli maka pembahasan yang akan dibahas juga tidak meluas.

\footnotetext{
${ }^{1}$ Hendi Suhendi, “Fiqh Muamalah”, (Jakarta: Raja Grafindo Persada 2002), h. 114.

${ }^{2}$ Sohrah, Aktualisasi Konsep Ekonomi Adil Menurut Al-Qur'an, Jurnal el-Iqtishady, Vol. 2 Nomor 1 (diakses Juni 2020)

${ }^{3}$ Yusuf al-Qardhawi, “Fatwa-Fatwa Kontemporer”, (Jakarta: Gema Insani, 2001), h. 67.
}

Iqtishaduna: Jurnal Ilmiah Mahasiswa Jurusan Hukum Ekonomi Syariah 
Beberapa kenyataan harus disadari bahwa negara kita bukan negara Islam terlebih dengan beredarnya makanan minuman yang haram sehingga lahirlah peraturan gubernur Nusa Tenggara Timur nomor 44 tahun 2019 meskipun isinya mengatur tentang penjualan dan pendistribusian sehingga barang tersebut tetap banyak beredar, di samping itu petugas atau aparat pemerintah daerah sulit atau jarang melakukan tindakan penertiban terhadap ketentuan dalam peraturan gubernur tersebut.

Permasalahan di Kelurahan Nangamese Kecamatan Riung Kabupaten Ngada, terdapat masalah mengenai minuman keras, yang sampai saat ini masih menjadi perbincangan hangat tentang akibat dari mengkonsumsi minuman keras beralkohol tersebut dikalangan masyarakat. Reaksi masyarakat terhadap penjualan minuman keras ini, ada sebagian masyarakat yang menolak dan ada pula yang memilih untuk acuh tak acuh atau tidak peduli. Adapun alasan yang menolak karena pembeli yang mengkonsumsi minuman keras beralkohol tersebut umumnya kerap melakukan tindakan diluar norma seperti keributan, perkelahian, penganiayaan, hingga pembunuhan.

Diketahui bahwa pengembangan ekonomi Islam yang bersandar pada hukum-hukum Islam memang harus mengalami persaingan yang berat karena makanan dan minuman yang tidak dijamin kehalalannya (haram) juga berkembang. Oleh karenanya makanan minuman yang halal tetap harus berjalan dan dikembangkan secara profesional karena merupakan tanggung jawab kepada Tuhan, khususnya umat Islam di kelurahan Nangamese tetap mengembangkan aspek-aspek ekonomi yang halal dengan harapan optimis bahwa kebutuhan makanan dan minuman yang halal akan lebih bermanfaat bagi kesehatan jasmani maupun rohani manusia sehingga masyarakat non muslim akan menyadarinya, meskipun ini adalah tantangan masyarakat mayoritas muslim di kelurahan Nangamese.

Hukum Islam yang mengatur tentang larangan penjualan minuman keras yang memabukan, Allah telah melarang segala sesuatu yang berkaitan dengan minuman keras karena merusak diri dan pikiran. Dalam hal ini Allah swt. berfirman dalam Q.S alMaidah: 91

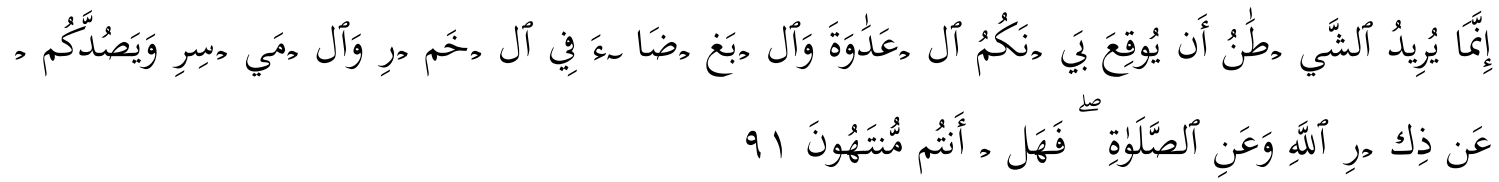

Terjemahnya:

"Sesungguhnya syaitan itu bermaksud hendak menimbulkan permusuhan dan kebencian di antara kamu lantaran (meminum) khamar dan berjudi itu, dan menghalangi kamu dari mengingat Allah dan sembahyang; Maka berhentilah kamu (dari mengerjakan pekerjaan itu). Dan taatlah kamu kepada Allah dan taatlah kamu kepada Rasul-(Nya) dan berhati-hatilah. Jika kamu berpaling, maka ketahuilah bahwa sesungguhnya kewajiban Rasul Kami, hanyalah menyampaikan (amanat Allah) dengan terang". 4

${ }^{4}$ Bachtiar Surin, “Terjemahan dan Tafsir al-Qur'an”, (Bandung: Fa, Sumatra, 1978), h. 62.

Iqtishaduna: Jurnal IImiah Mahasiswa Jurusan Hukum Ekonomi Syariah 
Terdapat juga dalam hadis Rasulullah SAW:

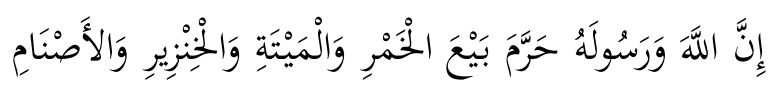

Terjemahnya:

"Sesungguhnya, Allah dan Rasul-Nya mengharamkan jual beli khamar, bangkai, babi, dan patung" (HR. Bukhari no. 2236 dan Muslim, no. 4132). ${ }^{5}$

Mengacu pada hal-hal tersebut di atas maka penulis tertarik untuk meneliti tentang praktik jual beli minuman keras tradisional pada masyarakat kelurahan Nangamese dalam karya tulis ilmiah dengan judul "Tinjauan Hukum Ekonomi Islam Terhadap Praktik Jual Beli Moke (Studi Kasus Kel. Nangamese, Kec. Riung, Kab. Ngada).”

\section{B. METODE PENELITIAN}

Jenis penelitian yang digunakan dalam karya tulis ini adalah penelitian hukum Islam. Adapun jenis penelitian hukum Islam yang dilakukan dalam penelitian ini yakni dengan melakukan kajian dalam berbagai literatur hukum Islam berupa aturan hukum yang diambil dari kompilasi hukum Islam, peraturan-peraturan serta literatur yang memuat mengenai konsep-konsep teoritis, serta mengambil fakta-fakta yang ada di dalam suatu masyarakat, badan pemerintah, ataupun badan hukum yang selanjutnya dihubungkan dengan sub permasalahan yang akan dibahas dalam karya tulis ini.

\section{HASIL DAN PEMBAHASAN}

\section{Praktik Jual Beli Moke di Kelurahan Nangamese}

Praktik penjualan moke di kelurahan Nangamese dilakukan dengan cara terbuka, para pembeli yang ingin meminum langsung ke rumah penjual untuk membeli, setiap penjual sudah mempunyai pelanggan tetap yang sering datang untuk membeli minuman. Apabila seseorang menjual barang kepada pembeli dengan dasar saling rela dan bukan karena paksaan, dan barang yang dibeli tersebut dibayar menggunakan uang atau dengan barang sesuai dengan kesepakatan dari masing-masing pihak.

a. Penjualan Dilakukan Dengan Cara Terbuka

Penjualan moke dilakukan dengan cara terbuka atau tidak disembunyikan dan tidak ada larangan dari pihak yang berwajib mengenai penjualan moke tersebut.

Ibu Julaiha selaku penjual mengungkapkan bahwa:

"Penjualan moke di sini memang tidak disembunyikan, bahkan hampir semua masyarakat sudah mengetahui siapa yang jual moke disini."

Hal sama juga diungkapkan oleh ibu Reli penjual moke yang juga mengungkapkan bahwa:

\footnotetext{
${ }^{5}$ Ahmad Ifham Sholihin, Pedoman Umum Lembaga Keuangan Syariah, (Jakarta: Gramedia Pustaka Utama, 2013), h. 489.

${ }^{6}$ Wawancara, Julaiha, Penjual Moke di Kelurahan Nangamese, Pada Tanggal 25 April 2021
}

Iqtishaduna: Jurnal IImiah Mahasiswa Jurusan Hukum Ekonomi Syariah 
"Semua orang yang jual moke di sini memang tidak pakai sembunyi-sembunyi karena kalau sembunyi-sembunyi orang tidak tau kalau kita jualan moke".?

Sebagaimana juga diungkapkan oleh Ibu Rosita bahwa:

"Penjualan moke memang tidak sembunyi-sembunyi karena yang jualan bukan hanya satu atau dua orang, kalau kita jual sembunyi-sembunyi nanti orang tidak tau kalau kita jualan itu barang (moke). Lagi pula tidak ada juga larangan mengenai penjualan moke ini". 8

Mengkonsumsi minuman keras adalah salah satu bentuk penyimpangan sosial. Penyimpangan sosial yang terjadi dikalangan remaja tidak akan begitu saja muncul apabila tidak ada faktor penarik atau faktor pendorong. Faktor penarik ada di luar diri seseorang, sedangkan faktor pendorong berasal dari dalam diri atau keluarga yang memungkinkan seseorang untuk melakukan penyimpangan tersebut.

b. Pembeli yang Mendatangi Penjual

Pembeli yang langsung mendatangi rumah penjual karena sudah mengetahui tempat penjualan. Sebagaimana hasil wawancara dengan Ibu Julaiha:

"Kalau yang mau beli mereka sendiri yang datang ke rumah, kami yang sebagai penjual ini hanya duduk jual di rumah tidak pergi tawar ke mereka yang mau beli",9

Hal yang sama juga diungkapkan oleh Ibu Reli:

"Memang begitu sudah mereka yang mau minum yah mereka yang datang cari di kami yang sebagai penjual ini karena inikan bukan barang makanan atau minuman yang semua orang suka atau mau beli supaya kita pergi tawar ke orang-orang, inikan hanya orang-orang tertentu yang mau beli"'10

Demikian juga yang dijelaskan oleh Ibu Rosita penjual moke di kelurahan Nangamese:

"Begitu sudah, yang mau minum yang datang beli. Ada juga yang tidak langsung datang ke rumah, kalau yang begitu mereka hubungi dulu lewat telepon tanya ada moke atau tidak nanti kalau lagi ada stoknya mereka baru datang beli supaya tidak buang cape datang baru sampai sini tidak ada mereka bilang". 11

Keingintahuan atau motif ingin tahu, bahwa peminum selalu mempunyai sifat selalu ingin tahu segala sesuatu yang belum atau kurang diketahui dampak negatifnya. Misalnya saja, ingin tahu bagaimana rasanya moke. Kesempatan, karena kesibukan orang tua maupun keluarga dengan kegiatannya masing-masing atau akibat broken home ataupun karena stres. Yaitu kurangnya perhatian dari keluarga atau kurangnya kasih sayang dari orang tua sehingga membuat mental seorang anak menjadi frustasi, brutal dan susah diatur.

\footnotetext{
${ }^{7}$ Wawancara, Reli, Penjual Moke di Kelurahan Nangamese, Pada Tanggal 25 April 2021

${ }^{8}$ Wawancara, Rosita, Penjual Moke di Kelurahan Nangamese, Pada Tanggal 27 April 2021

${ }^{9}$ Wawancara, Julaiha, Penjual Moke di Kelurahan Nangamese Pada Tanggal 25 April 2021

${ }^{10}$ Wawancara, Reli, Penjual Moke di Kelurahan Nangamese, Pada Tanggal 25 April 2021

${ }^{11}$ Wawancara, Rosita, Penjual Moke di Kelurahan Nangamese, Pada Tanggal 27 April 2021
}

Iqtishaduna: Jurnal IImiah Mahasiswa Jurusan Hukum Ekonomi Syariah 


\section{c. Setiap Penjual Sudah Mempunyai Pelanggan Tetap}

Setiap penjual sudah mempunyai pelanggan tetap yang sering datang ke rumah untuk membeli moke. Sebagaimana hasil wawancara dengan Ibu Julaiha penjual moke yang mengungkapkan bahwa:

"Saya mengetahui pelanggan tetap saya dan hafal siapa-siapa saja yang sering datang kesini". ${ }^{12}$

Hal yang sama juga diungkapkan oleh Ibu Reli penjual moke di kelurahan Nangamese:

"Moke yang saya jual ini, sudah banyak pelanggan atau orang yang sering datang beli, karena biar tengah malam kalau ada yang datang beli tetap saya layani jadi tidak kenal waktu makanya banyak yang mau minum langsung ke sini saja". ${ }^{13}$

Demikian juga yang diungkapkan oleh Ibu Rosita:

"Hampir semua penjual di sini sudah ada semua pelanggan karena biasanya rasanya itu beda-beda tiap moke jadi yang sudah rasa moke di sini kalau mereka suka maka mereka akan datang terus untuk beli di sini". ${ }^{14}$

Berdasarkan paparan data di atas temuan penelitiannya tentang praktik jual beli moke di kelurahan Nangamese adalah:

a. Penjualan moke dilakukan dengan cara terbuka karena tidak adanya larangan dari pihak yang berwajib.

b. Pembeli yang Mendatangi Penjual. Pembeli yang langsung mendatangi rumah penjual karena sudah mengetahui tempat penjualan.

c. Sebagaimana hasil wawancara dengan setiap penjual sudah mempunyai pelanggan tetap yang sering datang untuk membeli moke.

\section{Sikap Masyarakat Minoritas Islam di Kelurahan Nangamese, Kecamatan Riung dalam Menghadapi Tantangan dan Peluang Peredaran Moke}

Manusia hakikatnya tidak lepas dari bantuan orang lain dimana saling ketergantungan satu sama lain, itu sudah menjadi takdir dari manusia sebagai makhluk sosial untuk saling membantu salah satunya dalam jual beli. Kita ketahui dalam jual beli ada beberapa aturan-aturan ataupun syarat-syarat yang sudah ditetapkan. Maka dari itu, ketentuan tersebut patut diterapkan dalam melakukan kegiatan jual beli, dimana hal tersebut sudah menjadi ketentuan dari syariat Islam sendiri yang sepatutnya dijadikan dasar dalam melakukan sistem jual beli. ${ }^{15}$

\footnotetext{
${ }^{12}$ Wawancara, Julaiha, Penjual Moke di Kelurahan Nangamese, Pada Tanggal 25 April 2021

${ }^{13}$ Wawancara, Reli, Penjual Moke di Kelurahan Nangamese, Pada Tanggal 25 April 2021

${ }^{14}$ Wawancara, Rosita, Penjual Moke di Kelurahan Nangamese, Pada Tanggal 27 April 2021

${ }^{15}$ Nurhikma, Hamsir dan Ashar Sinilele, Tinjauan Hukum Islam Terhadap Jual Beli Hasil Tani Secara Tebasan (Studi Kasus Di Kecamatan Uluere Kabupaten Bantaeng, Jurnal Iqtishaduna Volume 2 Nomor 2 (diakses September 2020)
} 
Moke bagi masyarakat Nusa Tenggara Timur (NTT) dianggap sebagai simbol adat dalam pelaksanaan acara adat. Minum moke di dalam budaya masyarakat Nusa Tenggara Timur khususnya di masyarakat Flores telah menjadi tradisi turun-temurun di dalam upacara-upacara adat tertentu. Meneruskan tradisi ini, di satu sisi, dirasakan sebagai sebuah keharusan bagi masyarakat, tetapi di sisi lain, ada hal-hal yang dirasa tidak sesuai dengan etika umum masyarakat Indonesia. Pelanggaran etika tersebut terjadi ketika seseorang harus mengkonsumsi moke hingga mabuk. Hal ini dirasa akan semakin menjadi suatu permasalahan ketika pemerintah setempat, melalui kebijakannya, melegalkan keberadaan minuman tersebut sebagai salah satu minuman tradisional yang akan diproduksi dan dipasarkan secara masal. ${ }^{16}$

Berikut ini, pandangan masyarakat dalam menghadapi tantangan dan peluang peredaran moke:

Menurut pandangan bapak Maal Biguna mengatakan bahwa:

"Moke itu minuman keras atau miras hanya saja orang-orang di sini menyebutnya yah moke yang sudah jelas keharamannya, di dalam agama sudah ada larangannya". ${ }^{17}$ Demikian juga yang dikatakan oleh ibu $\mathrm{Hj}$. Sunarti bahwa "Moke itu barang yang tidak baik, dapat menyebabkan orang mabuk". ${ }^{18}$

Berdasarkan pandangan yang dikemukakan memang sudah jelas keharamannya, sesuai dengan sabda Nabi Muhammad saw.:

"Setiap minuman yang memabukkan, maka haram hukumnya". Dalam hadis tersebut sudah sangat jelas, dan minuman yang memabukkan itu hukumnya haram, walaupun dikonsumsi dengan jumlah yang sedikit. Dan dianggap sebagai hal yang bermanfaat bagi kesehatan. ${ }^{19}$

Minuman keras ini memang menjadi masalah dalam kehidupan masyarakat karena banyak sekali mudharatnya dibanding manfaatnya, sering kita lihat ada tindakantindakan yang tidak sesuai agama dan norma-norma, sehingga masyarakat ada yang terasa terganggu dengan keberadaannya, hal ini sesuai dengan yang dikemukakan oleh $\mathrm{H}$. Abubakar bahwa:

"Moke ini merupakan sesuatu yang sangat banyak mudharatnya, dapat meresahkan masyarakat sebab sering kali masyarakat yang mengkonsumsi ini melakukan tindakan-tindakan yang tidak baik sehingga mengganggu masyarakat yang lainnya, seperti ada yang teriak-teriak sampai dengan ugal-ugalan saat berkendara". ${ }^{20}$

Dengan mudharat yang ditimbulkan masyarakat, keberadaan menjadi hal yang sepatutnya tidak diinginkan oleh masyarakat terlebih akibatnya apabila seseorang yang telah mengkonsumsi moke melakukan tindakan seperti berteriak-teriak di kampung dan

\footnotetext{
${ }^{16}$ Andini Fransiska Dhapa Saka, Tinjauan Teori Compliance tentang Tradisi Minum Moke di Kabupaten Ende Nusa Tenggara Timur, andinisaka0902@gmail.com, (diakses pada 4 Mei 2019)

${ }^{17}$ Wawancara, Maal Biguna, Masyarakat Kelurahan Nangamese, Pada Tanggal 27 April 2021

${ }^{18}$ Wawancara, Hj. Rabiah, Masyarakat Kelurahan Nangamese, Pada Tanggal 27 April 2021

${ }^{19}$ Ahmad Ifham Sholihin, Pedoman Umum Lembaga Keuangan Syariah, (Jakarta: Gramedia Pustaka Utama, 2013), h. 490.

${ }^{20}$ Wawancara, H. Abubakar, Masyarakat Kelurahan Nangamese, Pada Tanggal 28 April 2021
}

Iqtishaduna: Jurnal Ilmiah Mahasiswa Jurusan Hukum Ekonomi Syariah 
mengganggu kenyamanan warga bahkan ketika sampai ugal-ugalan di jalanan ketika mabuk ini sangat meresahkan masyarakat sebab sangat membahayakan. Penjualan moke mampu merusak generasi mudah karena dengan muda didapatkan di area kampung, hal ini menyebabkan anak muda atau remaja mampu mengkonsumsi tanpa diketahui oleh orang tua mereka. Yang awalnya hanya coba-coba sampai akhirnya rutin karena telah kecanduan. Pengawasan yang kurang oleh pihak orang tua dan keluarga memang menjadi problem, tidak membatasi pergaulan anak, membiarkan bergaul dengan orang dewasa yang sering mengkonsumsi minuman keras menjadikannya gampang terpengaruhi. Bukan hanya itu keberadaan penjualan ini memang masih susah dihentikan, adapun penjelas oleh Ibu Kartini mengenai hal ini adalah:

"Hampir semua orang yang muslim di kampung ini sudah tahu bahwa moke itu haram, akan tetapi masih banyak yang meminumnya, di kampung ini pun ada pembuat sekaligus menjual langsung kepada pembeli, hal ini memang tidak baik bagi kampung karena menimbulkan nama kampung yang tidak baik di luar, meskipun penjualan ini merupakan mata pencarian untuk sebagian masyarakat tapi tidak mesti hal ini dikerjakan terus menerus, perlu ada peringatan atau pun sosialisasi bagi penjual bahwa moke itu merupakan minuman haram yang mempunyai banyak dampak bagi tubuh, untuk itu perlu kerja sama masyarakat untuk bagaimana cara kedepan agar penjualan moke ini menurun dan kalau perlu dihilangkan". ${ }^{21}$

Untuk menghentikan peredaran ataupun pembuatan moke diperlukan upaya, terlebih mereka menjadikan ini sebagai mata pencarian, keleluasaan menjual memang menjadi faktor yang memudahkan mereka melakukannya, dengan konsumen yang banyak menjadikan penjualan susah dihentikan, kerja sama antara pihak pemerintah dan masyarakat memang diperlukan, baik itu berupa himbauan atau peringatan terhadap bahaya minuman keras. Adanya penjualan minuman keras membuat nama daerah atau kampung jadi tidak baik dimata orang, masyarakat luar cenderung beranggapan bahwa banyak moke sehingga apabila orang ingin mencari minuman tersebut langsung saja ke kelurahan Nangamese, hal ini memang menjadi sebuah kabar yang tidak enak didengar oleh masyarakat yang tidak berprofesi sebagai penjual moke, salah seorang masyarakat merasa tidak senang apabila kampung dicap seperti itu, hal ini dikatakan oleh bapak Husni yakni:

"Saya terasa terusik dengan adanya penjual moke di kampung ini, karena saya yang berprofesi sebagai wiraswasta kadang kala mendengar bahwa di kampung ini ada penjual moke, hal ini menjadikan kampung dikenal di luar tetapi dengan cara yang salah, andai kampung terkenal akan prestasi maka saya pun pasti akan merasa bangga, berbeda dengan hal ini saya merasa kecewa. Dan memang perlu adanya tindak lanjut walaupun tidak hilang setidaknya dikurangi". ${ }^{2}$

Kekecewaan pasti akan muncul ketika apa yang diharapkan tidak sesuai dengan kenyataannya, begitulah kondisinya, masyarakat merasa kecewa karena di kampung

\footnotetext{
${ }^{21}$ Wawancara, Kartini, Masyarakat Kelurahan Nangamese, Pada Tanggal 28 April 2021

${ }^{22}$ Wawancara, Husni, Masyarakat Kelurahan Nangamese, Pada Tanggal 28 April 2021
} 
bukan hanya ada penjual moke saja tetapi di kelurahan Nangamese kini banyak pengusaha-pengusahanya dan berbagai profesi lain yang begitu membanggakan.

Keharaman dan larangan dalam agama memang telah diketahui oleh penjual moke, akan tetapi dengan dalih untuk memenuhi kebutuhan mereka tetap melakukan pekerjaan tersebut, faktor ekonomi memang tidak bisa dianggap remeh. Menjual moke telah menjadi mata pencarian tambahan bagi sebagian masyarakat setempat, akan tetapi perlu adanya perbaikan dan adanya upaya pemberitahuan bahkan mengubah moke untuk tidak dijual, bapak Maal Biguna mengemukakan

"Bahwa moke sebaiknya dijadikan cuka saja hal ini wajar-wajar saja dan baik disantap bersama ikan bakar. Akan tetapi ketika dijadikan untuk minum-minum ini sangat bahaya karena dapat menimbulkan orang mabuk dan menimbulkan halhal yang bahaya". 23

Keberadaan penjual ini memang harus diperhatikan, bukan hanya sekedar mengingatkan tetapi perlu upaya dari berbagai pihak, dengan kerja sama antar masyarakat memang hal ini bisa dilakukan. Adapun menurut ibu Rosmawati yakni:

"Ada beberapa upaya bisa dilakukan untuk menanggulangi dengan cara memberikan sosialisasi dan peringatan kemudian selanjutnya para penjual ini bisa dicarikan pekerjaan lain semisal tukang pengrajin tanah liat". ${ }^{24}$

Selain dijadikan moke air dari hasil irisan pohon lontar atau nira ini dijadikan gula oleh beberapa orang yang biasa disebut dengan gula aren, sehingga tidak hanya moke yang dapat dihasilkan. Tetapi karena kebanyakan orang menginginkan hasil yang instan atau cepat maka dari itu mereka memilih untuk melakukan penjualan moke yang pada dasarnya tidak hanya moke yang bisa dihasilkan dari hasil irisan pohon lontar atau enau tersebut, masih banyak peluang peningkatan ekonomi halal yang bisa dihasilkan. Dimana kegiatan produk air enau yang banyak tumbuh dapat dijadikan peluang usaha lainnya selain moke.

Dapat disimpulkan mengenai persepsi masyarakat-masyarakat di kelurahan Nangamese terhadap keberadaan penjual moke yakni terbelah menjadi 2 ada yang setuju dan adanya tidak setuju. Adapun yang setuju beralasan bahwa penjualan moke ini merupakan pekerjaan atau mata pencarian untuk menambah penghasilan serta memenuhi kebutuhan sehari-hari bagi masyarakat. Untuk yang tidak setuju beralasan bahwa penjual minuman keras dapat memberikan dampak yang tidak baik bagi masyarakat dan daerah setempat serta mudharatnya banyak sehingga tidak baik untuk diperjual belikan.

\section{Ketentuan Hukum Ekonomi Islam Terhadap Jual Beli Minuman yang Diharamkan}

Kegiatan muamalah merupakan kegiatan yang melibatkan anggota masyarakat dalam pemenuhan kebutuhan sehari-hari. Jual beli merupakan salah satu cara transaksi untuk meningkatkan taraf hidup. Jual beli juga salah satu bentuk kegiatan ekonomi yang hakikatnya adalah saling tolong menolong sesama manusia, apalagi tolong menolong dalam Islam sangat dianjurkan dengan ketentuan hukum yang telah diatur dalam syariat

\footnotetext{
${ }^{23}$ Wawancara, Maal Biguna, Masyarakat Kelurahan Nangamese, Pada Tanggal 27 April 2021

${ }^{24}$ Wawancara, Rosmawati, Masyarakat Kelurahan Nangamese, Pada Tanggal 29 April 2021
} 
Islam.Dalam melakukan transaksi jual beli hal yang paling perlu diperhatikan yaitu mencari barang yang halal dengan cara yang halal juga. Perdagangan dengan cara jual beli merupakan sesuatu kegiatan yang halal, karena dapat mendatangkan manfaat yang besar bagi manusia dan juga masyarakat sebagai makhluk sosial. ${ }^{25}$

Seluruh hukum yang telah menjadi ketetapan aturan Allah swt. Untuk para hambaNya, baik dalam bentuk perintah maupun larangan mengandung maslahah. Semua perintah Allah swt. Dan sebaliknya semua perintah larangan Allah untuk dijauhi hambaNya terkandung kemaslahatan, yaitu dijauhkannya dari kelalaian dan kerusakan. Maslahah mursalah mempunyai definisi mutlaq atau fleksibel, dan dalam pandangan ulama ushul adalah tidak ada hukum ataupun dalil untuk menerapkannya karena maslahah mursalah diterapkan untuk mewujudkan kemaslahatan umat dalam memecahkan problematika, yang menjadi anggapan diakui tidaknya suatu kemaslahatan. Yaitu mencari jalan tengah dari suatu permasalahan dan bahwa kemaslahatan ini merujuk kepada semua orang atau tidak terbatas, dan kemaslahatan itu diikuti oleh perkembangan zaman globalisasi atau hukum Islam kontemporer. Minuman keras merupakan minuman yang bersifat memabukkan dan dapat membahayakan peminum terlebih kepada kaum remaja dan harus dihindari oleh kaum remaja karena itu akan berdampak pada masa depannya.

Ekonomi Islam merupakan salah satu pendekatan sistem ekonomi dalam pembentukan perekonomian masyarakat. Banyak Negara yang ada didunia ini melakukan pendekatan ekonomi konvensional dalam memenuhi kepentingan pribadi pendekatan ini umumnya lebih berkembang di dunia barat. Di balik keberhasilan tersebut, sesungguhnya mereka gagal mewujudkan aktualisasi visi sosial dan tujuan normatif ilmu ekonomi. ${ }^{26}$

Praktik jual beli moke di kelurahan Nangamese ditinjau dari hukum Islam melakukan jual beli yang haram misalnya minuman keras diharamkan dalam Islam. Penjualan moke tetap saja berlangsung karena dari pihak penjual dilakukan untuk memenuhi kebutuhan hidup.Jual beli yang dilakukan tidak boleh bertentangan dengan syariat agama Islam. Prinsip jual beli dalam Islam, tidak boleh merugikan salah satu pihak, baik penjual maupun pembeli. Jual beli harus dilakukan atas dasar suka sama suka, bukan karena paksaan. ${ }^{27}$ Hukum jual beli ada 4 macam, yaitu: ${ }^{28}$

a. Mubah (boleh), merupakan hukum asal jual beli.

b. Wajib, apabila menjual merupakan keharusan, misalnya menjual barang untuk menjual hutang.

c. Sunah, misalnya menjual barang kepada sahabat atau orang yang sangat memerlukan barang yang dijual.

d. Haram, misalnya menjual barang yang dilarang untuk diperjual belikan. Menjual barang untuk maksiat, jual beli untuk menyakiti seseorang, jual beli untuk

\footnotetext{
${ }^{25}$ Nurapriani, Ashabul Kahfi, Tinjauan Hukum Islam Terhadap Praktik Jual Beli Gabah Dengan Pembayaran Sebelum Panen, Jurnal Iqtishaduna Volume 2 Nomor 2 ( diakses September 2020)

${ }^{26}$ Mahmudah Mulia Muhammad, Membangun Sistem Ekonomi Islam Berorientasi Kesalehan Sosial, Jurnal el-Iqtishady Volume 1 Nomor 1 ( diakses Juni 2019)

${ }^{27}$ Nasruen Haruen, Fiqih Muamalah, (Jakarta: Gaya Media Pratama,2007), h. 76.

${ }^{28}$ Sayyid Sabiq, Fiqih Sunnah, (Bandung: PT. Al-Ma'arif, 1987), h. 43.
}

Iqtishaduna: Jurnal Ilmiah Mahasiswa Jurusan Hukum Ekonomi Syariah 
merusak harga pasar, dan jual beli dengan tujuan merusak ketentraman masyarakat.

Jual beli dikatakan sah apabila memenuhi syarat-syarat yang ditentukan. Persyaratan itu untuk menghindari timbulnya perselisihan antara penjual dan pembeli akibat adanya kecurangan dalam jual beli. Rasulullah saw. melarang adanya tipuan dalam jual beli oleh karena itu seorang pedagang dituntut berlaku jujur dalam menjual dagangannya. ${ }^{29}$

Hal ini tidak sesuai menurut Larangan minum khamr (minuman keras), diturunkan secara berasngsur-angsur. Sebab minuman khamr itu, bagi orang Arab sudah menjadi hal yang mendarah daging semenjak zaman jahiliyah. Mula-mula, dikatakan bahwa minuman keras lebih banyak dosanya dibandingkan dengan manfaatnya. Kemudian seseorang yang sedang mabuk tidak boleh mengerjakan solat, dan yang terakhir dikatakan bahwa meminum khamr adalah perbuatan yang keji dan termasuk perbuatan setan. Oleh sebab itu, hendaklah orang-orang yang beriman menjauhi khamr. ${ }^{30}$

Di dalam hadis riwayat Ahmad Abu Hurairah diterangkan sebab turunnya ayat mengenai perintah untuk menghindari khamr:

Ketika Rasulullah saw. datang ke Madinah, didapatinya orang-orang minum khamr dan berjudi. Lalu para sahabat bertanya kepada Rasulullah saw. tentang hukumnya, maka turunlah ayat tersebut. Mereka memahami dari ayat tersebut bahwa minum khamr dan berjudi itu tidak diharamkan, tetapi hanya dikatakan bahwa, pada keduanya terdapat dosa yang besar. Sehingga mereka masih tetap minum khamr. Ketika waktu sholat magrib, tampillah seorang Muhajirin menjadi imam, lalu dalam shalat tersebut bacaannya banyak yang salah, karena sedang mabuk setelah minum khamr. Maka turunlah firman Allah yang lebih keras dari yang sebelumnya: ${ }^{31}$

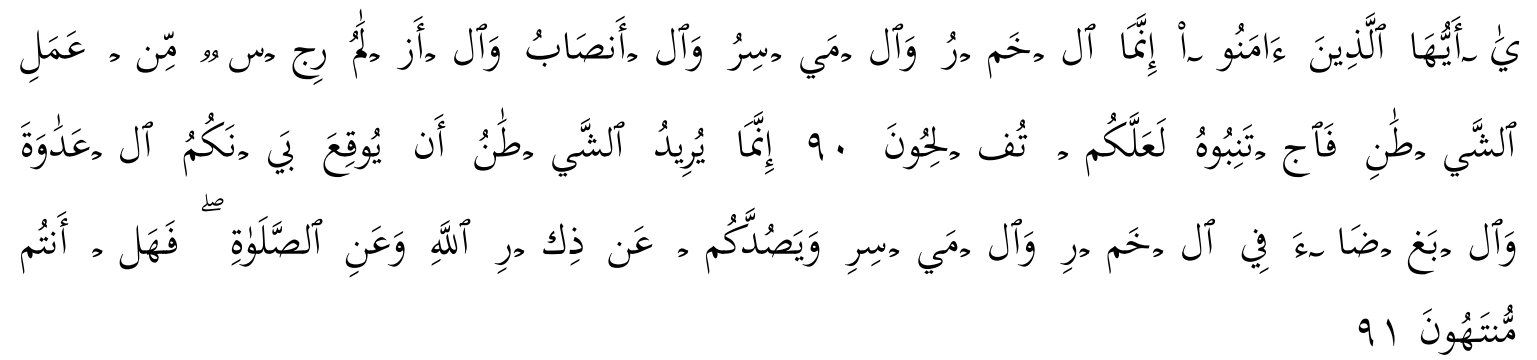

Terjemahnya:

"Hai orang-orang yang beriman, Sesungguhnya (meminum) khamar, berjudi, (berkorban untuk) berhala, mengundi nasib dengan panah, adalah termasuk perbuatan syaitan. Maka jauhilah perbuatan-perbuatan itu agar kamu mendapat keberuntungan. Sesungguhnya syaitan itu bermaksud hendak menimbulkan permusuhan dan kebencian di antara kamu lantaran (meminum) khamar dan berjudi itu, dan menghalangi kamu dari mengingat Allah dan sembahyang; Maka berhentilah kamu (dari mengerjakan pekerjaan itu)". (QS: Al Maidah, 90-91).

\footnotetext{
${ }^{29}$ Nasruen Haruen, Fiqih Muamalah, (Jakarta: Gaya Media Pratama,2007), h. 88.

${ }^{30}$ Bachtiar Surin, Terjemah dan Tafsir al-Qur'an, (Bandung:Fa Sumatra 1978), h. 63.

${ }^{31}$ Bachtiar Surin, Terjemah dan Tafsir al-Qur'an, (Bandung:Fa Sumatra 1978), h. 63.

${ }^{32}$ Departemen Agama RI, al-Qur'an dan Terjemahnya. (Bandung : PT. Sygma Examedia Arkanleema, 2009), h. 77.
}

Iqtishaduna: Jurnal Ilmiah Mahasiswa Jurusan Hukum Ekonomi Syariah 
Sebagaimana diketahui bahwa antara moke dan khamr adalah sama. Dengan berbagai perbedaan dan intinya berujung pada persamaan dalam segi unsurnya, yaitu sama-sama memabukkan. Maka dalam hal ini moke adalah khamr dan sebaliknya khamr itulah moke. Meskipun khamr bermula dari perasan anggur, dimana perkembangannya di masa sekarang sudah bukan hanya dari sebuah bahan dasarnya yang menjadikan tolak ukur untuk bisa disebut khamr, moke yang berbahan dasar dari pohon aren atau enau pun sudah jelas itu juga khamr.Seperti yang dijelaskan sebelumnya, moke adalah salah satu jenis minuman keras atau minuman beralkohol yang mengandung zat etanol. Jika dikonsumsi dalam jumlah yang banyak dapat menyebabkan kemabukan. Maka moke juga segala sesuatu yang memabukkan disebut khamr. ${ }^{33}$

Dari sini agaknya kita bisa memahami bahwa khamr itu sebaiknya wajib dihindari karena banyak sekali sisi keburukan atau mudharatnya bagi manusia bahkan yang melanggar aturan Tuhan akan diberikan siksaan berat di akhirat kelak, ini menunjukkan betapa beratnya dampak negatif dari khamr. Tetapi ironisnya di Indonesia yang mayoritas beragama Islam terkhusus di NTT tidak menyebutkan dan menawarkan solusi ampuh terhadap hal ini, di NTT juga tidak menetapkan jenis hukuman yang pantas diberlakukan kepada pelaku khamr, baik yang telah mengkonsumsi atau yang akan mengkonsumsinya nanti. Namun yang terjadi di NTT adalah sebaliknya, bukan membuat undang-undang khusus yang berkaitan dengan pelaku khamr, atau memberlakukan hukuman untuk pelakunya. Tetapi memperbolehkan khamr tersebut dikonsumsi dan dipasarkan secara legal, bahkan telah di undang-undangkan dalam Peraturan Gubernur NTT. ${ }^{34}$ dengan memandang manfaatnya dimana dapat meningkatkan perekonomian masyarakat NTT khususnya.

Banyak orang yang sudah terjerumus dirinya ke dalam lubang khamr atau narkoba susah selamat dari hal itu, bahkan harus mengeluarkan dana yang sangat banyak demi memuaskan ketagihan dan ketergantungan terhadap benda-benda haram itu. Padahal setiap akal dan jiwa manusia wajib dilindungi, apalagi sisi manfaat khamr hanya dinikmati oleh segelintir orang seperti penjual, pengedar, pemakai dan perusahaan yang membuat khamr.

Begitu banyak yang memahami konsep mengenai lebih besarnya dosa ataupun kerugian yang dihasilkan oleh moke atau khamr daripada manfaatnya, tetapi dalam penerapan terhadap kehidupan sehari-hari apalagi sudah menjadi tradisi, hal tersebut sangat sulit dilakukan. Karena kembali lagi kepada niat seseorang masing-masing, apabila dia mau untuk berhenti secara perlahan, dengan pengharaman oleh Allah swt. terhadap khamr yang juga secara bertahap, pasti akan bisa berhenti meminum moke dengan sendirinya. Namun apabila tidak ada sedikitpun niat untuk berhenti, tidak akan terlaksana meskipun banyak konsep dan pembelajaran untuk membuat seseorang berhenti meminum moke.

${ }^{33}$ Sulaiman Al-Faifi, Ringkasan Fikih Sunnah Sayyid Sabiq, (Depok: Semja Media Utama, 2019), h. 592.

${ }^{34}$ Peraturan Gubernur Nusa Tenggara Timur Nomor 44 tahun 2019

Iqtishaduna: Jurnal IImiah Mahasiswa Jurusan Hukum Ekonomi Syariah 


\section{KESIMPULAN}

Berdasarkan pembahasan diatas, penulis mengambil kesimpulan:

1. Praktik jual beli moke di kelurahan Nangamese dilakukan dengan cara terangterangan atau terbuka karena tidak ada larangan dari pihak yang berwajib, kemudian untuk pembeli atau yang ingin mengkonsumsi moke tersebut mereka yang mendatangi penjual untuk bertransaksi langsung dan yang ketiga setiap penjual sudah mempunyai pelanggan tetap

2. Sikap masyarakat minoritas Islam di kelurahan Nangamese Kecamatan Riung Kabupaten Ngada dalam menghadapi tantangan dan peluang peredaran moke yaitu terbelah menjadi dua ada yang setuju dan ada yang tidak setuju. Masyarakat yang tidak setuju telah mengetahui bahwa moke merupakan minuman yang haram karena telah ada larangannya yang jelas di dalam al-Qur'an dan hadis. Masyarakat yang setuju pun menyatakan bahwa moke memiliki beberapa manfaat salah satunya menghilangkan rasa capek. Terlepas dari manfaat ada beberapa dampak bagi tubuh yang dirasakan seperti kepala pusing, perut kembung dan mabuk.

3. Ketentuan hukum ekonomi Islam terhadap jual beli minuman yang diharamkan moke merupakan minuman yang dilarang, karena moke itu minuman beralkohol yang dari segi unusr, jenis, rasa, warna, maupun akibat yang dapat ditimbulkan dari keduanya adalah sama dengan khamr. 


\section{DAFTAR PUSTAKA}

\section{Buku}

al-Qardhawi Yusuf, Fatwa-Fatwa Kontemporer, Jakarta: Gema Insani, 2001.

Departemen Agama RI, al-Qur'an dan Terjemahnya, Bandung PT. Sygma Examedia Arkanleema, 2009.

Haruen Nasruen, Fiqih Muamalah, Jakarta: Gaya Media Pratama, 2007.

Sabiq Sayyid, Fiqih Sunnah, Bandung: PT. Al-Maarif, 1978.

Sholihin Ahmad Ifham, Pedoman Umum Lembaga Keuangan Syariah, Jakarta: Gramedia

Pustaka Utama, 2013.

Suhendi Hendi, Fiqh Muamalah, Jakarta: Raja Grafindo Persada 2002.

Sulaiman Al-Faifi, Ringkasan Fikih Sunah Sayyid Sabiq, Depok: Semja Media Utama, 2019.

Surin Bachtiar, Terjemah dan Tafsir al-Qur'an, Bandung: Fa Sumatra 1978.

\section{Jurnal}

Mahmudah Mulia Muhammad, Social Entrepreneurship Mewujudkan Kesejahteraan Masyarakat Berdasarkan Prinsip-Prinsip Ekonomi Syariah, Jurnal el-Iqtishady

Volume 2 Nomor 2 (diakses Desember 2020)

Nurapriani, Ashabul Kahfi, Tinjauan Hukum Islam Terhadap Praktik Jual Beli Gabah

Dengan Pembayaran Sebelum Panen, Jurnal Iqtishaduna Volume 2 Nomor 2 (diakses September 2020)

Nurhikma, Hamsir dan Ashar Sinilele, Tinjauan Hukum Islam Terhadap Jual Beli Hasil Tani Secara Tebasan (Studi Kasus Di Kecamatan Uluere Kabupaten Bantaeng, Jurnal Iqtishaduna Volume 2 Nomor 2 (diakses September 2020)

Sohrah, Aktualisasi Konsep Ekonomi Adil Menurut al-Qur'an, Jurnal el-Iqtishady Volume 2 Nomor 1 (diakses Juni 2020)

\section{Peraturan-peraturan}

Peraturan Gubernur Nusa Tenggara Timur Nomor 44 tahun 2019

\section{Website}

Andini Fransiska Dhapa Saka, Tinjauan Teori Compliance tentang Tradisi Minum Moke di Kabupaten Ende Nusa Tenggara Timur, andinisaka0902@gmail.com, (diakses pada 4 Mei 2019)

\section{Wawancara}

Wawancara Masyarakat Kelurahan Nangamese, Pada Tanggal 27 April 2021 